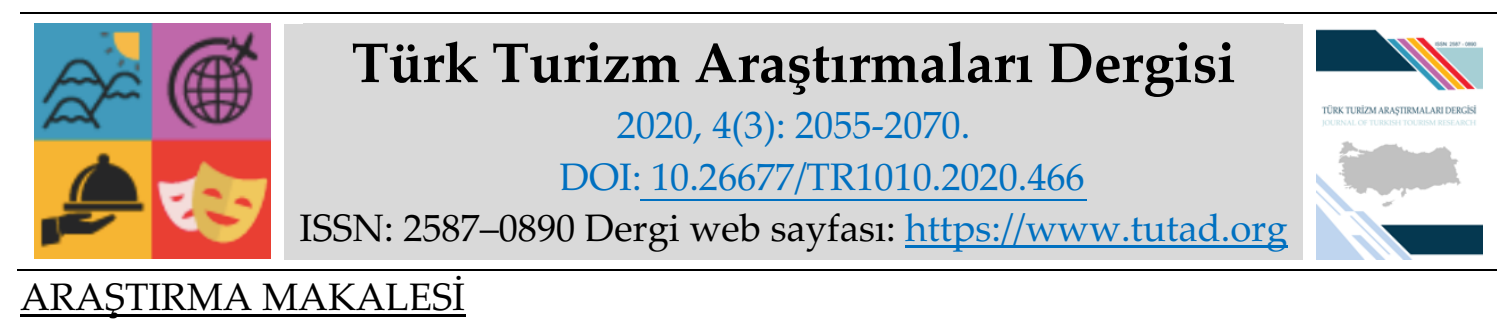

\title{
İnanç Turizmi Kapsamında Aksaray Somuncu Baba Külliyesi'nin YouTube Video Analizi
}

Dr. Öğr. Üyesi Mehmet TUNCER, Aksaray Üniversitesi, Turizm Fakültesi, Aksaray, e-posta: mehmettuncer@aksaray.edu.tr ORCID: https://orcid.org/0000-0001-5929-4902

Arş. Gör. Grant Altay TAŞKIN, Aksaray Üniversitesi, Turizm Fakültesi, Aksaray, e-posta: grantaltaytaskin@hotmail.com

ORCID: https://orcid.org/0000-0001-6689-7728

\section{Öz}

Seyahat edenler, destinasyon tercihlerinde sosyal medya sitelerindeki fotoğraf, video veya yazılı paylaşımlardan etkilenmektedirler. Dünyada ve Türkiye'de İnanç turizmi kapsamında ziyaret edilen birçok nokta bulunmaktadır. Sosyal medyanın pazarlama gücünden yararlanarak daha az bilinen inanç turizm merkezleri daha bilinir hale gelmektedir. Yapılan bu çalışmada yaşamının önemli bir bölümünü Aksaray'da olmak üzere Kayseri, Bursa ve Malatya'da sürdürmüş olan Şeyh Hamid-i Veli (Somuncu Baba) adına Aksaray'da yaptırılmış külliyenin bilinirliğinde YouTube'da paylaşılmış olan videoların etkisi araştırılmıştır. Bu çalışmada YouTube video paylaşım sitesinde "Somuncu Baba Külliyesi" anahtar kelimesi ile tarama yapılmış, en çok görüntülenmeye sahip olan 5 video üzerinde söylem analizi metoduyla inceleme gerçekleştirilmiştir. Somuncu Baba'ya ithaf edilen birçok mekân olmasına rağmen çalışma Aksaray Somuncu Baba külliyesi ile sınırlandırılmıştır. Araştırmadan elde edilen sonuçlara göre, daha uygun video içerikleri oluşturulduğunda mekâna ilişkin videoların daha fazla izlenebileceği ve mekânın tanınırlık ve bilinirliğinin artacağı anlaşılmaktadır. Böylece Aksaray'ın inanç ve kültür turizmi bağlamında Somuncu Baba Külliyesinden daha fazla yararlanabileceği söylenebilir.

Anahtar Kelimeler: Somuncu Baba, İnanç, YouTube, Söylem Analizi.

Makale Gönderme Tarihi: 06.03.2020

Makale Kabul Tarihi: 02.07.2020

\section{Önerilen Atıf:}

Tuncer, M. ve Taşkın, G. A. (2020). İnanç Turizmi Kapsamında Aksaray Somuncu Baba Külliyesi'nin YouTube Video Analizi, Türk Turizm Araştırmaları Dergisi, 4(3): 2055-2070.

(C) 2020 Türk Turizm Araştırmaları Dergisi. 


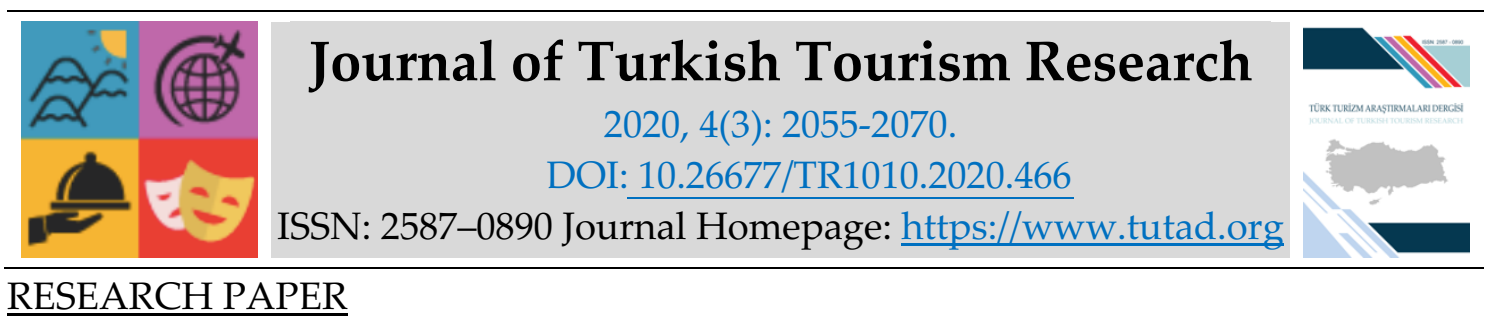

\title{
YouTube Video Analysis of the Islamic Social Complex of Somuncu Baba in Context with Religious Tourism
}

Assistant Prof. Dr. Mehmet TUNCER, Aksaray University, Faculty of Tourism, Aksaray, e-mail: mehmettuncer@aksaray.edu.tr ORCID: https://orcid.org/0000-0001-5929-4902

Research Assistant Grant Altay TAŞKIN, Aksaray University, Faculty of Tourism, Aksaray, email: grantaltaytaskin@hotmail.com

ORCID: https://orcid.org/0000-0001-6689-7728

\begin{abstract}
Travelers are impressed by pictures, videos and writings in social media when they are choosing their holiday destination. There are a lot of religious destinations around the world and in Turkey. Thanks to the marketing power of social media, recondite religious destinations can become better known now. In this study, the aim is to find out the impact of social media on the awareness of the Islamic Complex of Şeyh Hamid-i Veli (Somuncu Baba) who spent his life mostly in Aksaray but also in Kayseri, Bursa and Malatya. In this study, "Somuncu Baba Külliyesi" is used as a keyword and the keyword is searched via YouTube. The outcome is limited by the first five video which have got viewed the most and the videos are examined using discourse analysis. Although there are many complexes dedicated to Somuncu Baba, this study only focuses on the one in Aksaray. According to the results of the research, when better video contents are created the videos will be watched more and consequently the knowledge and recognition level will increase. Thus, Aksaray will benefit from the complex much more in the context of religious tourism and cultural tourism.
\end{abstract}

Keywords: Somuncu Baba, Religion, YouTube, Discourse Analysis.

Received: 06.03.2020

Accepted: 02.07.2020

\section{Suggested Citation:}

Tuncer, M. and Taşkın, G. A. (2020). YouTube Video Analysis of the Islamic Social Complex of Somuncu Baba in Context with Religious Tourism, Journal of Turkish Tourism Research, 4(3): 20552070.

(C) 2020 Türk Turizm Araştırmaları Dergisi. 


\section{Gíriş}

İnsanlar farklı beklentilerle turistik hareketlere katılmakta ve sunulan turistik ürünlere verdikleri tepkilerinin sonucu olarak turizmde dönüşüm ve değişim yaşanmaktadır. Bunun nedenini, Göğebakan (2015:51-52) eğitim düzeyindeki ilerleme, insanların yaşam standartlarının artması ve turizm bilincindeki yükseliş olarak açıklamaktadır. Bir başka ifade ile turistler, önceki dönemlerde herhangi bir amaç olmadan da seyahat ederlerken, şimdilerde gidecekleri destinasyonu araştırarak hareket etmekte ve daha bilinçli bir şekilde seyahatlerini gerçekleştirmektedirler (Emekli, 2005:101).

Turizm alanında gelişme hedefinde olan ülkelerin ürün çeşitlendirme gerekliliği kaçınılmaz bir olgudur (Güzel, 2010:88). Bu gelişimi sağlamada, destinasyon pazarlamasına önemli görevler düşmektedir. Destinasyon pazarlamasında markalaşmadan da yararlanılmaktadır. Tuncer (2018:118) bu kapsamda, turistik bir destinasyonun çekiciliğinin artmasında markalaşmanın önemli bir yere sahip olduğunu, kendiliğinden var olan doğal bir oluşumun bile markalaşma ve pazarlama çabalarına ihtiyaç duyacağını ifade etmektedir.

Kitle iletişim araçlarının gelişmesi ile bir yerin tanıtımı ve bilinirliğinin arttırılmasında internet ve sosyal medyadan öncelikli olarak yararlanılmaktadır. Buna yönelik yurt içinde ve dışında çeşitli çalışmalar yapılmaktadır. Yurt dışında yapılan çalışmalardan birinde, yıllar önce ortaya çıkan ve rekorlar kıran "Gangnam Style" isimli şarkının YouTube üzerinden paylaşılması ile Kore turizminin olumlu yönde etkilendiği ifade edilmektedir (Koo vd., 2013). Türkiye'de yapılmış bir çalışmada ise, devlet kurumlarının, acentelerin ve turizm işletmelerinin tanıtım ve pazarlama amacıyla interneti yoğun bir şekilde kullandıkları, ayrıca turistlerin deneyimlerini Travelblog, YouTube, Facebook, Flickr ve TripAdvisor gibi sosyal alanlardan paylaşarak destinasyonların bilinirliklerine katkı sağladıkları ifade edilmektedir (Çakmak ve Altaş, 2018:391). Bu durum bir destinasyonun veya bir turistik değerin tanıtılmasında sosyal medya araçlarının ne kadar etkili olduğunu göstermektedir.

Bu çalışmada nispeten daha az bilinen bir inanç ve kültür merkezi olan Somuncu Baba Külliyesi hakkındaki video paylaşımları, YouTube video paylaşım sitesi üzerinden incelenmiştir. Hayatının önemli bir bölümünü, Aksaray sınırlarında geçiren Somuncu Baba hakkında bilgi karmaşası olduğu görülmüştür. Bu çalışmada, Somuncu Baba ve ona ithaf edilen külliyeye ilişkin hazırlanan videoların incelenmesi ile tanıtımda görülen eksikliklerin ortaya konması amaçlanmıştır. Elde edilecek sonuçlarla daha etkili video içerikleri oluşturma anlamında önerilerde bulunulmuştur.

\section{KAVRAMSAL ÇERÇEVE}

Günümüzde turizm farklı alt başlıklar altında incelenmektedir. Bu konuda Kozak (2014) katılan kişi sayısına göre (grup, kitle, bireysel), ziyaret edilen yere göre (iç, dış), katılanların yaşlarına göre (genç, yetişkin, üçüncü yaş), sosyo-ekonomik duruma göre (sosyal, lüks) veya amaca göre (deniz, kongre, termal, yat, mağara, dağ ve kış, av, golf, inanç, yayla, akarsu) gibi turizmin farklı şekillerde sınıflandırıldığını açıklamaktadır. Turizmin dönüşmesi, değişmesi ve kitle turizminin olumsuz etkilerinin en aza indirilmesi gerekçesi, "alternatif turizm" ve "özel ilgi turizmi" gibi kavramların ortaya çıkmasını sağlamıştır (Çel, 2011:334). Alternatif turizm tiplerinden biri olan kültür turizmi 20. yüzyılın sonlarından itibaren her toplumun kendi kültürel değerlerini pazarlayarak turizm pastasından pay alma isteği ile ortaya çıkmıştır (Jovicic, 2014:608-609).

Kültür turizmi; kültürel bir motivasyon sebebiyle, yani: eğitim almak, sanatını sergilemek, festival ve etkinliklere katılmak, sit alanları ve antları görmek, dinsel hac ziyaretleri yapmak, doğa, halk ve sanatı keşfetmek amaçlı seyahatleri içermektedir (Wang vd., 2010:555). Kültür 
turizminin yukarıda bahsedilen farklı boyutları ile gelişim gösterdiğine ilişkin çeşitli veriler elde edilmektedir. Bunlardan birinde Türkiye'nin köklü acentelerinden Prontotour'un 2019 yılı ilk üç ayına ait yurtiçi kültür turu sayısının 2018 yılına göre \%300 artış gösterdiği görülmüştür (Yılmaz, 2019). Dünya geneli ile ilgili olarak yapılan başka bir çalışmada ise, tüm gezilerin \%37'sinin kültür turizmi amacıyla yapıldığı ifade edilmektedir (Alaeddinoğlu ve Yıldız, 2011:21). Yukarıda bahsedilen istatistiki verilerden de anlaşılacağı üzere, kültür turlarına olan ilgi giderek artmaktadır.

Kültür turizmi içerisinde yer alan önemli kavramlardan birisi de inanç turizmidir. Bir diğer ismi spritüal turizm olarak ifade edilen kavram, kutsal alanlarda belirli ritüelleri gerçekleştirmek adına insanların yaptığı ziyaretler olarak tanımlanmaktadır. Özellikle Anadolu topraklarında havra, camii, kilise ve türbeler inanç turizm alanları olarak öne çıkmaktadır (Eser, Şahin ve Çakıcı, 2018:127). İlk çağlardan bu yana insanlar inanç temelli seyahatlere katılmaktadırlar ancak, bu seyahatlerin turizmdeki gelişimi 1990'lı yıllardan itibaren hızlanmıştır (Türker, Akça ve Uçar, 2019:112). Yukarıdaki ifadelerden de anlaşılacağı üzere insanlar hem farklı kültürlere ait inançları keşfetmek hem de kendi inançları doğrultusunda ziyaretler gerçekleştirmektedirler.

Türkiye'de özellikle yerli turistlerin inanç turizmi bağlamında ziyaret ettikleri yerler incelendiğinde Selimiye, Süleymaniye ve Sultan Ahmet gibi camilerin yanı sıra Hacıbektaş Dergâhı, Mevlâna Müzesi gibi merkezler yoğun bir şekilde talep görmektedir. Araştırma konusunu oluşturan Somuncu Baba da yukarıda sayılan merkezler gibi yoğun turist çekme potansiyeline sahiptir. Ancak mevcut durum dikkate alındığında tanıtımın yeterince yapılmadığı için çok fazla turist çekemediği düşünülmektedir. Bu anlamda Somuncu Baba'dan genel anlamda bahsetmek yerinde olacaktır.

Somuncu Baba, Horasan'ın erenlerinden olan Şemseddin Musa Hazretlerinin oğludur ve bir manevi davete icabet edildiği sıra Kayseri'de dünyaya gelmiştir. İlk eğitimini babasından, sonrasında ise Kayseri ulemasından almayı sürdürmüştür (Ulu, 2016:17-18). Babasının ölümünün ardından Şam'a bir yolculuk yaparak bir şeyhin huzurunda senelerce hizmet vermiştir. Ardından Tebriz ve Erdebil'de de bulunan Şeyh Hamid-i Veli, birkaç seyahat daha yaptıktan sonra Somuncu Baba ismini alacağı Bursa'ya yerleşmiştir (Başer, 1995:14-15). Somuncu Baba'nın Bursa'dan önce Darende (Malatya)' de ve Kayseri'de bir süre kaldığını belirten Akgündüz (2009: 62), hatta mürşidi olan Hacı Bayram-1 Veli ile ilk defa orada görüştüğünü belirtmektedir. Somuncu Baba'nın hayatının son günlerini geçirdiği yer için iki şehir ön plana çıkmaktadır. Bunlardan biri Aksaray diğeri ise Darende (Malatya)'dır. Başer (1995), Bursa'dan ayrılan Somuncu Baba'nın sırasıyla Kayseri, Şam ve Hac ziyaretleri yaptığını ve Aksaray'da vefat ettiğini belirtmektedir.

Genelde Aksaray, Malatya, Kayseri ve Bursa şehirleri ile ilişkilendirilen Şeyh Hamid-i Veli (Somuncu Baba) Anadolu'yu manevi olarak fetheden erenlerdendir. Celâleddin Rumi, Hacı Bayram-1 Veli gibi dervişlerin bilinirliğinin yanında Somuncu Baba'nın da toplumdaki yeri ve saygınlığı oldukça fazladır (Akgündüz, 2009: 24). Somuncu Baba gibi tarihimizde ve halkımız üzerinde önemli etkilere sahip kişilerin türbe, mezar, camii gibi yapılar, inanç turizmi merkezleri arasında yer almaktadır. İnanç turizmi faaliyetine katılma eğilimi taşıyan birçok potansiyel turist olmasına rağmen, bunların bu destinasyonlara ilişkin yeterince bilgi sahibi olmamaları önemli bir eksikliktir. Bu çerçevede bilgi eksikliğini gidermede, internet ve sosyal medyadan daha fazla yararlanılabilinir.

Turizm hareketine katılmak isteyen ve seyahat motivasyonu olan kişiler için asıl soru nereye seyahat edecekleri ve nasıl bir tatil planlayacaklarıdır. Günümüzde bu noktada bilgi toplamak ve nereye seyahat edileceğine karar vermek için internetten sıklıkla yararlanılmaktadır (JiménezBarreto vd., 2020:1). İnternetin önemini anlayan turistik destinasyonlar veya işletmeler 
kendilerine ait web sayfaları, Facebook, Twitter, YouTube gibi sosyal medya hesapları ve mobil aplikasyonlar kullanmaktadırlar (Zhang vd., 2018:1095). Böylece doğrudan tüketicilere bilgi akışı sağlanabilmektedir.

Bilgi akışının sağlanmasında, yaygın kullanımı nedeniyle YouTube'nin öne çıktığı görülmektedir. YouTube; bireylerin profil oluşturabildiği, özgürce videolar yükleyip paylaşabildiği ve dilediği videolardan oynatma listesi oluşturabildiği evrensel bir platformdur (Reino ve Hay, 2011: 2). YouTube, insanların kişisel bir kanal kurabilmesine, insanların paylaşımlarını bu kanal üzerinden yapabilmesine ve gezip gördükleri yerlere ilişkin bilgi aktarımına fırsat veren bir sosyal medya aracı olarak gittikçe önemini artırmaktadır.

Bu çalışmada az bilindiği var sayılan Aksaray Somuncu Baba Külliyesine yönelik 5 adet YouTube videosu incelenmiştir. Paylaşımı yapan kişi veya kurum, video süresi, söylem analizi, tıklanma ve beğeni sayıları ile ilgili değerlendirmelerde bulunulmuştur. Dünya çapında en gözde video paylaşım platformları arasında gösterilen YouTube'deki Somuncu Baba Külliyesi anahtar kelimesiyle yapılan arama sonucunda karşılaşılan videoların geliştirilmesi ve içeriklerinin düzenlenmesi konusunda çeşitli öneriler geliştirilip sunulmuştur.

\section{YÖNTEM}

Yapılan bu araştırmada, en etkili video paylaşım sitelerinden biri olarak kabul edilen YouTube' de Aksaray Somuncu Baba Külliyesine ilişkin videolar incelenmiştir. Konuya ilişkin birçok video olmasına rağmen araştırmada en fazla görüntülenen beş videoya yer verilmiştir. Söz konusu bu videoların 5.12.2019 tarihinde "Somuncu Baba Külliyesi" anahtar kelimesi ile YouTube üzerinden taraması gerçekleştirilmiştir.

Araştırmada içerik analizi tekniği uygulanmıştır. İçerik analizinin kullanım alanları; yazılı dokümanlar, fotoğraflar, videolar ve ses yakıtları ile sağlanan iletişimlerdir. Bu çalışmada videolarda geçen konuşmalar analiz edilmiştir. Yine bir başka tanımda söylem analizi; yazılı metin, konuşma veya görsel iletişim gibi söylemlerin özelliklerinin analizi olarak ifade edilmektedir (Çomu, 2012:107). Tarihteki ilk söylem analizi 1960'larda konuşmadaki birçok unsuru inceleyen multidisipliner bir çalışma alanı olarak görülmüştür (Solak, 2011:3). Söylem analizi Çelik ve Ekşi'nin 2008 yılındaki yaptıkları çalışmalarında, gelişmekte olan heterojen yapılı bir nitel çalışma olarak ifade edilmektedir. Böylece söylem analizi ile uygun içerik oluşturulup oluşturmadığ ile ilgili değerlendirme yapmak mümkün olmuştur.

Tablo 1. Video Paylaşım Sitesi İçin Söylem Analizi Modeli

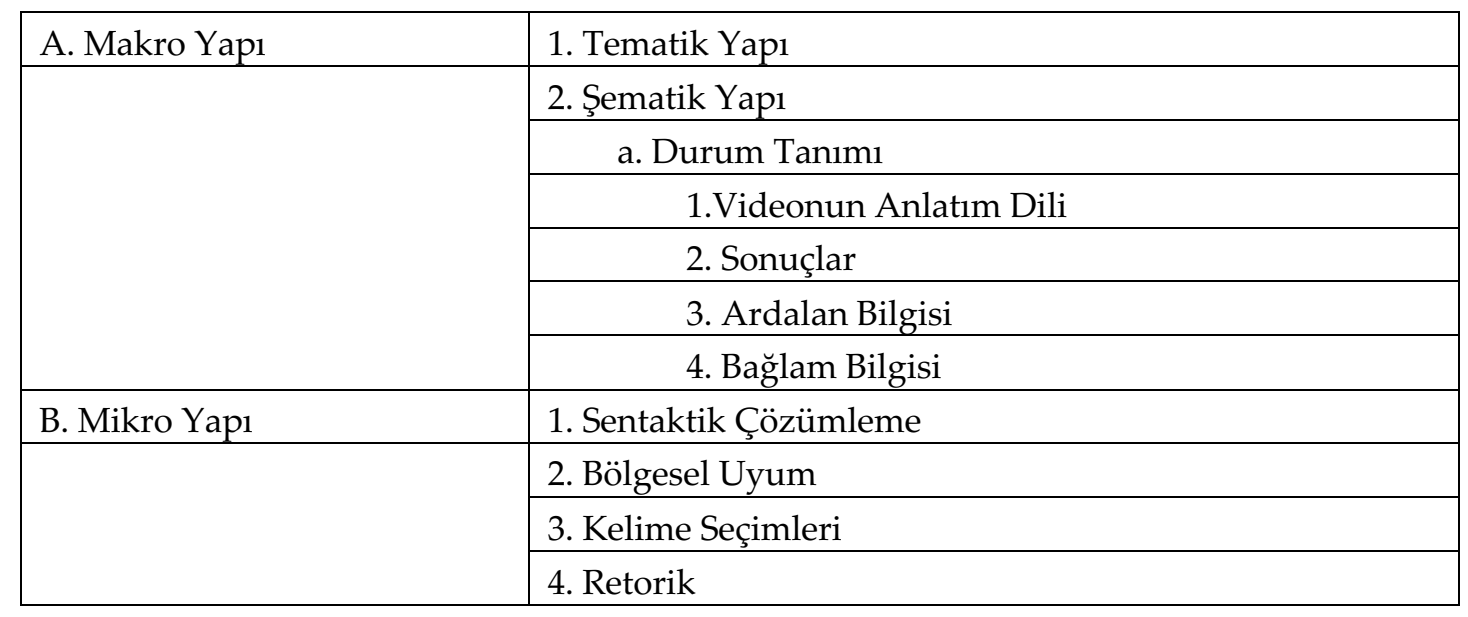


Çalışmanın konusunu oluşturan Somuncu Baba Külliyesi ile ilişkili videolar Çomu (2012: 139) tarafından oluşturulan şablon ve Dondurucu ve Uluçay'ın 2015'te kullandıkları model aynen uygulanarak hazırlanmıştır. Bu bağlamda videoların; başlık, url, süre, tarih, izlenme sayısı, beğenilme ve beğenilmeme sayısı, olumlu, olumsuz ve nötr yorum sayısı, kategori, tanım ve diğer sosyal ağlara link verip vermeme gibi özellikleriyle künyesi oluşturulmuştur. Sonrasında Tablo 1'de görülen makro ve mikro yapı analizleri uygulanmıştır.

\section{BULGULAR ve YORUM}

Bu çalışmada 05.12.2019 tarihinde YouTube video paylaşım sitesinde yayınlanmış beş (5) video analiz edilmiştir. En çok izlenen bu videolar sırasıyla; "Somuncu Baba / Aksaray Trt Belgeseli / Gönül Sultanları", "Somuncu Baba Türbesi Ziyaretçi Akınına Uğruyor", "Aksaray Somuncu Baba Türbesi", "Aksaray Somuncu Baba Çilehane”, ve "Somuncu Baba'nın Minyatür Müzesini Yılda 500 Bin Turist Ziyaret Ediyor" videolarıdır.

Tablo 2. YouTube' de Yer Alan "Somuncu Baba / Aksaray Trt Belgeseli / Gönül Sultanları" Başlıklı Videonun Söylem Çözümlemesi (Video-1)

\begin{tabular}{|l|l|}
\hline Başlık & Somuncu Baba / Aksaray Trt Belgeseli / Gönül Sultanları \\
\hline URL & https://www.youtube.com/watch?v=ggdLqoYUsio \\
\hline Süre & $28: 35: 00$ \\
\hline Yayınlanma Tarihi & 14 Aralık 2015 \\
\hline İzlenme Sayısı & 18.578 \\
\hline Beğenilme Sayısı & 142 \\
\hline Beğenilmeme Sayısı & 9 \\
\hline Yorum Sayısı & 12 \\
\hline Olumlu Yorum Sayısı & 9 \\
\hline Olumsuz Yorum Sayısı & 1 \\
\hline Nötr Yorum Sayısı & 2 \\
\hline Kategori & Kişiler ve Bloglar \\
\hline Tanım & Tanım bulunmamaktadır \\
\hline $\begin{array}{l}\text { Diğer Sosyal Ağlara } \\
\text { veya Web Sitelerine } \\
\text { Link Verme Durumu }\end{array}$ & Bu videoda herhangi bir link verilmemiştir. \\
\hline
\end{tabular}

\section{A. Makro Yapı}

\section{Tematik Yapı}

Video başlı̆̆ında yazılı olan "Somuncu Baba / Aksaray TRT Belgeseli / Gönül Sultanları" ile içeriğin birbiriyle uyumlu olduğu saptanmıştır. Belgesel formatında olması ve Somuncu Baba'nın hayatı ve ününe dair bilgiler içermesi özelliğiyle de başlıkla birebir uyuştuğu söylenebilir. Video için herhangi bir tanım yazılmamıştır. Kategori olarak kişiler ve bloglar şeklinde sınıflandırılma yapılmıştır. Video için herhangi bir etiket kullanılmamıştır.

\section{2. Şematik Yapı}

Durum 
1.Videonun Anlatım Dili: Videoda başta Aksaray Somuncu Baba Külliyesi ve Aksaray'ın turistik değerleri olmak üzere Kayseri, Bursa gibi şehirlerden görüntüler üzerine açıklayıcı, tanımlayıcı ifadeler yer almaktadır. Ney ile çalınan tasavvufi müzikler üzerine dingin ve huzur veren bir ses ile anlatılmıştır. Anlatım, dini bir sembol olarak ün salan Şeyh Hamid-i Veli belgeseline yakışır bir biçimde Bismillâhirrahmânirrahîm bir başka ifade ile, Rahman ve Rahim olan Allah'ın adıyla diye başlamaktadır. Anlatım çoğunlukla sözlü olmuş, zaman zaman şehir isimlerine yer verilmiştir.

2. Sonuçlar: Sade ve akıcı bir dil kullanılmıştır. Anlatıcı videonun içerisinde bulunmamaktadır.

3. Ardalan Bilgisi (Önceki olay da dahil): İncelenen videoda ardalan bilgisine rastlanmamıştır. Videoda kronolojik bir anlatım tercih edilmiş anlatım bir bütün halinde verilmiştir.

4. Bağlam Bilgisi: Video önce Somuncu Baba'nın günümüze gelen iki şiirinden birisi olan “Biz Ol Uşşak-ı Serbazuz" ile başlamakta ardından Somuncu Baba'nın doğumu, yaşantısı, mucizeleri, yaşadığ 1 şehirler ve ölümüyle birlikte örüntülü ifadelerle anlatılmıştır.

\section{B. Mikro Yap1}

1. Sentaktik Çözümleme: Cümlelere bakıldığında genel olarak pasif yapılı olduğu görülmektedir. Videodaki ifadeler ya geniş zaman ya da öğrenilen geçmiş zaman olarak çekimlenmiştir.

2. Bölgesel Uyum: Cümlelerde sıklıkla nedensel ilişki görülmektedir. “İlmini ve kendini gizlemek için bir fırıncı gibi yaşamaya başlar" gibi ifadeler yer almaktadır.

3. Kelimelerin Seçimleri: Videoda genellikle düz anlamlı kelimeler kullanılmıştır. Belgeselin akıcılı̆ının sağlanması ve daha net anlaşılması adına metaforlara sık yer verilmediği görülmüştür.

4. Retorik: Retorik unsurlara bakıldığında Somuncu Baba'nın Aksaray'daki ve diğer yaşadığ1 şehirlerdeki türbelerinden görüntülere yer verilerek inandırıcılık artırılmaya çalışılmıştır.

Tablo 3. YouTube'de Yer Alan "Somuncu Baba Türbesi Ziyaretçi Akınına Uğruyor" Başlıklı Videonun Söylem Çözümlemesi (Video-2)

\begin{tabular}{|l|l|}
\hline Başlık & Somuncu Baba Türbesi Ziyaretçi Akınına Uğruyor \\
\hline URL & https://www.youtube.com/watch?v=R4x-bU_dyCk \\
\hline Süre & 02:58 dakika \\
\hline Yayınlanma Tarihi & 2 Temmuz 2015 \\
\hline İzlenme Sayısı & 16.080 \\
\hline Beğenilme Sayısı & 101 \\
\hline Beğenilmeme Sayısı & 10 \\
\hline Yorum Sayısı & 14 \\
\hline Olumlu Yorum Sayısı & 4 \\
\hline Olumsuz Yorum Sayıs1 & 7 \\
\hline Nötr Yorum Sayısı & 3 \\
\hline Kategori & Film ve Animasyon \\
\hline
\end{tabular}




\begin{tabular}{|c|c|}
\hline Tanım & 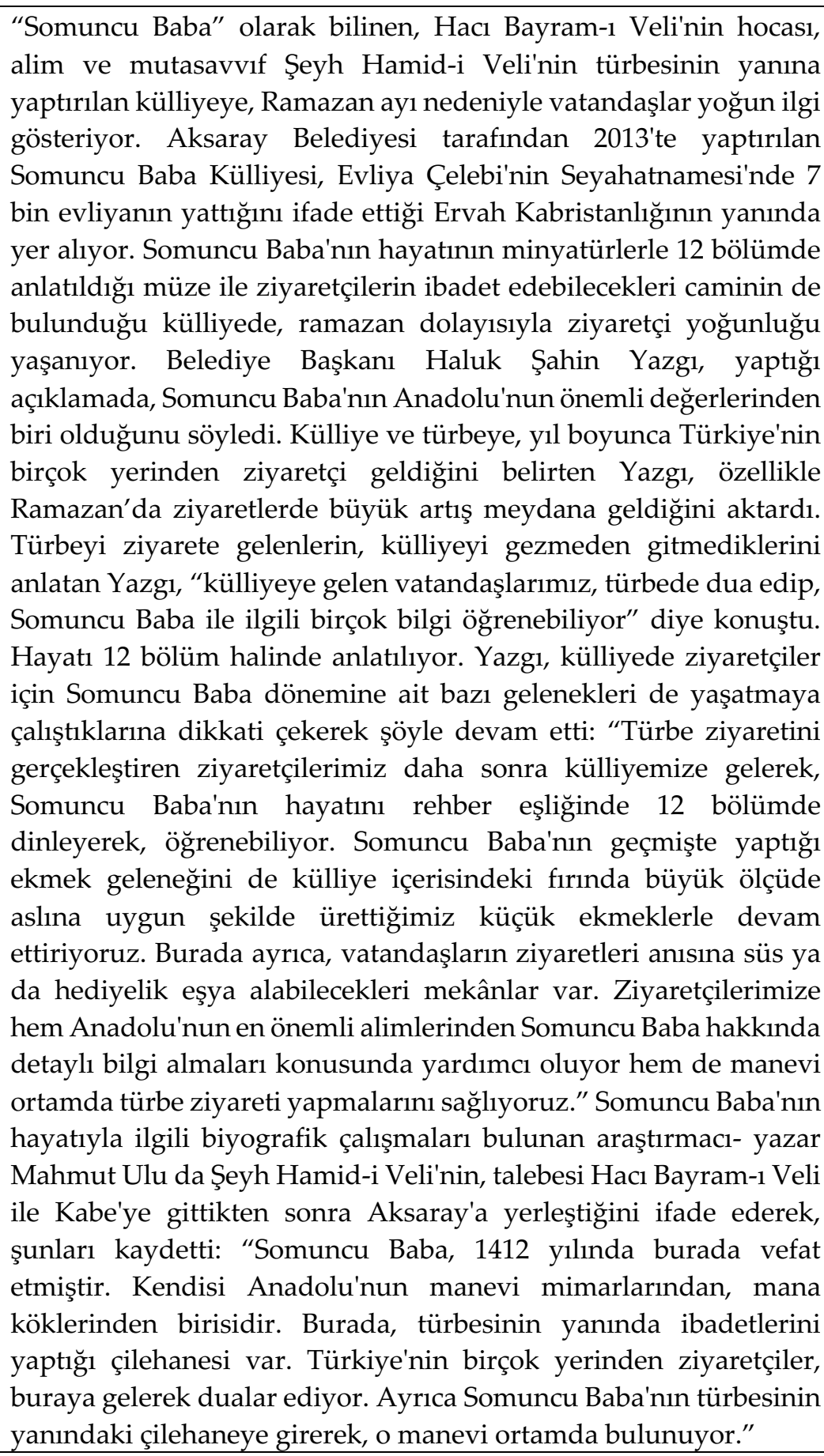 \\
\hline $\begin{array}{l}\text { Diğer Sosyal Ağlara } \\
\text { veya Web Sitelerine } \\
\text { Link Verme Durumu }\end{array}$ & Bu videoda herhangi bir link verilmemiştir. \\
\hline
\end{tabular}




\section{A. Makro Yapı}

\section{Tematik Yap1}

Tablo 3'de incelenen videoda "Somuncu Baba Türbesi Ziyaretçi Akınına Uğruyor" isimli başlık kullanılmıştır. Başlık ile içeriğin kısmen uyuştuğu görülmüştür. Daha çok Somuncu Baba'nın hayatına yer verilirken aynı zamanda gelen ziyaretçiler de videoda görülmekte ve röportajlara yer verilmektedir. Tanım, videodaki içerikle uyuşmakta ve hatta daha fazla ayrıntı içermektedir. Kategori olarak film ve animasyonun seçilmesinin, videoda "Somuncu Baba Aşkın Sırrı" filmine yer verilmesinden kaynaklandığı düşünülmektedir. Etiketlere bakıldığında videoda "Somuncu Baba Türbesi Ziyaretçi Akınına Uğruyor, Somuncu Baba, Somuncu Baba Aksaray, Aksaray, Somuncu Baba Türbesi, türbe, Hacı Bayram Veli, kanal 7, kanal 7 haber, ramazan ayı, Somuncu Baba Türbesi, Şeyh Hamid-i Veli, Aksaray Belediyesi, Haluk Şahin Yazgı, türbe ziyareti" kelimeleri seçildiği görülmüştür.

\section{2. Şematik Yapı}

Durum

1. Videonun Anlatım Dili: Konuşmalar basit ve sade bir dille yapıllp eksiksiz bir şekilde duyulmaktadır. Spiker, belediye başkanı ve ilahiyatçı araştırmacı yazarın ifadeleri net bir şekilde anlaşılmakta, fakat halk ile yapılan röportajlarda kişilerin duygu yüklü olması sebebiyle zaman zaman kelimelerin anlaşılırlığı yetersiz kalmaktadır.

2. Sonuçlar: Videonun genelinde Somuncu Baba'nın kim olduğundan ve Aksaray halkı için öneminden bahsedilmiştir.

3. Ardalan Bilgisi (Önceki olay da dahil): Videoda ardalan bilgisine rastlanmamıştır.

4. Bağlam Bilgisi: Videoda önce türbenin ziyaretçi akınına uğradığından ardından Somuncu Baba'nın kim olduğundan bahsedilmiş ve külliyenin bölümleri gösterilerek halkın oradaki ilgisi gözler önüne serilmiştir. Sıralanan ifadelerin örüntülü bir şekilde aktarıldığı tespit edilmiştir.

\section{B. Mikro Yapı}

1. Sentatik Çözümleme: Geçmiş zaman, geniş zaman ve şimdiki zaman ifadeleri kullanılmıştır. Aktif ve pasif yapılı cümlelerin her ikisine de yer verilmiştir.

2. Bölgesel Uyum: Cümlelerde nedensel ilişki bulunmaktadır. "Hacı Bayram-ı Veli'nin hocasıdır. Hacı Bayram-ı Veli de Akşemseddin'in hocasıdır. Dolayısıyla Akşemseddin de Fatih Sultan Mehmet'in hocasıdır. Yani İstanbul'u fetheden o zincirleme halkanın ilk başlangıç noktası Somuncu Baba Hazretleridir" ve "soyu yirmi dördüncü kuşaktan Hz. Peygamber'e uzanıor" gibi ifadeler halkın türbeye akın etmesinin sebebi olarak gösterilmektedir.

3. Kelimelerin Seçimleri: Kelimeler genelde düz anlamda kullanılmıştır. Türbe, fırın ve çilehane gibi bölümler kelime seçimlerini etkilemiştir.

4. Retorik: Somuncu Baba'nın yaşamını anlatan filmden verilen kesit, belediye başkanının açıklamaları ve videoda yer alan ziyaretçilere ilişkin duygu dolu görüntüler inandırıcılık düzeyini artırmaktadır. 
Tablo 4: YouTube Üzerinde Yer Alan “Aksaray Somuncu Baba Türbesi” Başlıklı Videonun Söylem Çözümlemesi (Video-3)

\begin{tabular}{|l|l|}
\hline Başlık & Aksaray Somuncu Baba Türbesi \\
\hline URL & https://www.youtube.com/watch?v=OIJZZugeCI0 \\
\hline Süre & $6: 20$ \\
\hline Yayınlanma Tarihi & 26 Ocak 2013 \\
\hline İzlenme Sayısı & 9.626 \\
\hline Beğenilme Sayısı & 21 \\
\hline Beğenilmeme Sayısı & 1 \\
\hline Yorum Sayısı & 2 \\
\hline Olumlu Yorum Sayısı & 0 \\
\hline Olumsuz Yorum Sayısı & 1 \\
\hline Nötr Yorum Sayısı & 1 \\
\hline Kategori & Kişiler ve Bloglar \\
\hline Tanım & $\begin{array}{l}\text { Aksaray Somuncu Baba Türbesi } \\
\text { Aksaray Merkez 68, Ihlara, Güzelyurt, Sultanhanı, Helvadere }\end{array}$ \\
\hline $\begin{array}{l}\text { Diğer Sosyal Ağlara } \\
\text { veya Web Sitelerine } \\
\text { Link Verme Durumu }\end{array}$ & Bu videoda herhangi bir link verilmemiştir. \\
\hline
\end{tabular}

\section{A. Makro Yapı}

\section{Tematik Yapı}

Video $3^{\prime}$ ün başlığı ile içeriğin uyumlu olduğu görülmektedir. Başlıktan Somuncu Baba Türbesi'nin tanıtılacağı düşünülmekte ve öyle de olmaktadır. Fakat görüntü ve ses kalitesi vasatın altındadır. Videonun tanımı tam olarak eşleşmemektedir. Videoda etikete rastlanmamıştır.

\section{2. Şematik Yapı}

Durum

1. Videonun Anlatım Dili: Videoyu hazırlayan kişi kendi bildiklerini aktarmakta ve türbe içerisindeki hoca ile röportaj gerçekleştirmektedir. Anlatım dili sadedir fakat zaman zaman cızırtılar sebebiyle ses net olarak anlaşılamamaktadır.

2. Sonuçlar: Halk diliyle çekilmiş, doğaçlama ve samimi bir anlatım söz konusudur.

3. Ardalan Bilgisi (Önceki olay da dahil): Önceki olaylar ile bağlantı kurulduğu tespit edilmiştir. "Mustafa hocam bize sağ olsun gezdirdi, istişare etti" ifadesiyle ardalan bilgisi verilmektedir.

4. Bağlam Bilgisi: Türbenin içinde başlayan anlatım daha sonra mezarda ve çilehanede devam etmektedir. Olayların bir örüntü içinde verildiği anlaşılmaktadır.

\section{B. Mikro Yap1}

1. Sentaktik Çözümleme: Videodaki cümleler genellikle aktif yapıdadır. Sıklıkla şimdiki zaman ve geçmiş zaman ifadelerine yer verilmiştir. 
2. Bölgesel Uyum: Videoda arka arkaya gelen cümleler birbirini açıklamaktadır. "Dar, çok dar, burası nedir Mustafa Hocam? Burası büyük evliyaların gelip 40 günlük ibadet ettiği yer değil mi? Böyle değil mi? Evet." ifadeleriyle nedensellik kurulmaktadır. Böylece bu yere ait koşulların zorluğu mekânı ilgi çekici hale getirmektedir.

3. Kelimelerin Seçimleri: Videoda yer alan kelimeler genellikle düz anlamda seçilmiştir ve anlaşılması kolaydır. "Sekiz, basamak, dar" gibi her kesimden insanın anlayabileceği türden kelimeler tercih edilmiştir.

4. Retorik: Kamera ile zorlu koşullarda yürüdükçe alınan sarsıntılı görüntüler ve video içerisinde yer alan kişilerin ziyaret sırasında yaşadıkları zorluklar, inandırıcılığı ortaya koymaktadır.

Tablo 5: YouTube'de Yer Alan "Aksaray Somuncu Baba Çilehane" Başlıklı Videonun Söylem Çözümlemesi (Video-4)

\begin{tabular}{|l|l|}
\hline Başlık & Aksaray Somuncu Baba Çilehane \\
\hline URL & https://www.youtube.com/watch?v=AGsFSGZ6RZE \\
\hline Süre & $04: 35$ \\
\hline Yayınlanma Tarihi & 18 Eylül 2017 \\
\hline İzlenme Sayısı & 1.438 \\
\hline Beğenilme Sayısı & 7 \\
\hline Beğenilmeme Sayısı & 2 \\
\hline Yorum Sayısı & 1 \\
\hline Olumlu Yorum Sayısı & 0 \\
\hline Olumsuz Yorum Sayısı & 1 \\
\hline Nötr Yorum Sayısı & 0 \\
\hline Kategori & Kişiler ve Bloglar \\
\hline Tanım & Aksaray Somuncu Baba Çilehane \\
\hline $\begin{array}{l}\text { Diğer Sosyal Ağlara } \\
\text { veya Web Sitelerine } \\
\text { Link Verme Durumu }\end{array}$ & Bu videoda herhangi bir link verilmemiştir. \\
\hline
\end{tabular}

\section{A. Makro Yapı}

\section{Tematik Yapı}

Bu video için seçilen "Aksaray Somuncu Baba Çilehane" başlığının içerik ile birebir uyduğu görülmektedir. Başlıkta belirtildiği gibi videonun içeriğinde Somuncu Baba'nın derviş geleneklerinden olan dar ve küçük bir odada oruç tutup ibadet ettiği çilehane tanıtılmaktadır. Video tanımı ismiyle aynı şekilde verilmiştir. Video "Aksaray, Somuncu Baba, baba, somun ve çilehane" olarak etiketlenmiştir.

\section{2. Şematik Yapı}

\section{Durum}

1. Videonun Anlatım Dili: Video, Somuncu Baba Çilehanesini ziyaret eden yerel bir muhabirin bilgilendirmeleri ve röportajı şeklinde izleyenlere aktarılmıştır. Anlatımlara bakıldığında genel olarak bilgi aktarmak ve farkındalığı tespit etmek hedeflenmiştir. 
2. Sonuçlar: Sade bir anlatım tercih edilmiştir. Çilehane içerisinde görüntülü bir anlatıma yer verilmiştir. Çilehane karşılıklı konuşmalar ve muhabirin anlatımlarıyla detaylı bir şekilde anlatılmıştır.

3. Ardalan Bilgisi (Önceki olay da dahil): İncelenen videoda "Şimdi aşağıda da zaten ibadet eden insanlar var" cümlesiyle önceden içeriye girilip bakıldığ bilgisi verilmiştir.

4. Bă̆lam Bilgisi: Çilehane kapısında bilgilendirme yapılıp içeriye girilmekte, içeride ibadet edenlerle sohbet edilip bilgi aktarımı yapılmakta ve çıkışta da tekrar yapılan röportaj ile anlatım sonlanmaktadır. Böylece olayların bir örüntü içerisinde verildiği görülmektedir.

\section{B. Mikro Yap1}

1. Sentatik Çözümleme: Anlatım dili oldukça sadedir. Videodaki konuşmalar, genellikle şimdiki zaman ve geniş zaman kipinde çekimlenmiştir.

2. Bölgesel Uyum: Video genelinde anlatılan çilehanenin kullanım sebebi ve bu destinasyonun ziyaret sebebi açılanmıştır. Cümleler arasında nedensellik görülmektedir.

3. Kelimelerin Seçimleri: Videodaki kelime tercihlerinin genellikle anlaşılır ve sade olduğu görülmektedir. Mekân tanıtımı için "dar, beş basamaklı" gibi kelimeler kullanılarak ziyaret zorluğu da iletilmektedir

4. Retorik: Bu videodaki anlatımlar görsellerle desteklenmekte, ziyaretçilerin doğaçlama olarak görüşleri alınmakta ve video kesilmemektedir. Dolayısıyla inandırıcılık üst düzeydedir.

Tablo 6. YouTube Üzerinde Yer Alan “Somuncu Baba'nın Minyatür Müzesini Yılda 500 Bin Turist Ziyaret Ediyor" Başlıklı Videonun Söylem Çözümlemesi (Video-5)

\begin{tabular}{|l|l|}
\hline Başlık & $\begin{array}{l}\text { Somuncu Baba'nın Minyatür Müzesini Yılda 500 Bin Turist } \\
\text { Ziyaret Ediyor }\end{array}$ \\
\hline URL & https://www.youtube.com/watch?v=wJdg-rWVv2Q \\
\hline Süre & $04: 11$ \\
\hline Yayınlanma Tarihi & 5 Kasım 2019 \\
\hline İzlenme Sayısı & 890 \\
\hline Beğenilme Sayısı & 8 \\
\hline Beğenilmeme Sayısı & 1 \\
\hline Yorum Sayısı & 5 \\
\hline Olumlu Yorum Sayısı & 1 \\
\hline Olumsuz Yorum Sayısı & 4 \\
\hline Nötr Yorum Sayısı & 0 \\
\hline Kategori & Haberler ve Politika \\
\hline Tanım & $\begin{array}{l}\text { Aksaray Belediyesi tarafından 2013 yılında açlan Somuncu } \\
\text { Baba Minyatür Müzesi yerli ve yabancı turistlerden yoğun ilgi } \\
\text { görüyor. Somuncu Baba'nın hayatı ve yaşam tarzının anlatıldığı } \\
\text { Somuncu Baba Minyatür Müzesi'nde 500'e yakın minyatür yer } \\
\text { alıyor. Somuncu Baba Külliyesi ve Kültür Merkezi'nde bulunan } \\
\text { müze bu yıl Aksaray Belediyesi tarafından yeniden }\end{array}$ \\
\hline
\end{tabular}




\begin{tabular}{|c|c|}
\hline & $\begin{array}{l}\text { düzenlenerek restore edildi. Müzeyle ilgili bilgiler veren } \\
\text { Belediye Başkanı Evren Dinçer, “2013 yllında açılmış olan } \\
\text { Somuncu Baba Minyatür müzemizin göreve geldikten sonra } \\
\text { tadilatını yaptık. Zemin yerleştirmeleri, ses sistemi, buradaki } \\
\text { minyatür onarımlar neticesinde şu anki haline getirmiş } \\
\text { bulunuyoruz. Yılda yaklaşık } 500 \text { bine yakın vatandaşımız } \\
\text { ziyaret ediyor. Ileri ki hedeflerimiz } 1 \text { milyona yakın } \\
\text { vatandaşımızı buraya çekebilmek. Biliyorsunuz ki Somuncu } \\
\text { Baba Hazretleri, Şeyh Hamidi Veli Hazretleri Erdebil'de } \\
\text { başlayan bir macerası Bursa, akabinde Malatya, oradan da } \\
\text { Aksaray'a geliyor. Hayatını, ömrünü Aksaray'da tamamlıyor. } \\
\text { Bu minyatürümüzde de 500'e yakın minyatür ile } 13 \text { safhadan } \\
\text { oluşan hayat seyrini minyatür olarak anlatmış bulunmaktayız. } \\
\text { Gerçekten tarihimize, manevi dünyamıza atıf yapan güzel bir } \\
\text { çalışma oldu” dedi. Müzeyi gezen ziyaretçiler ise müzenin çok } \\
\text { güzel olduğunu belirterek, "Somuncu Baba'nın hayatında } \\
\text { yaşamış gibi oluyoruz. Belediyemize teşekkür ederiz" }\end{array}$ \\
\hline $\begin{array}{l}\text { Diğer Sosyal Ağlara } \\
\text { veya Web Sitelerine Link } \\
\text { Verme Durumu }\end{array}$ & $\begin{array}{l}\text { Bu videoda İhlas haber ajansının resmî web sitesine ve sosyal } \\
\text { medya hesaplarına link verilmektedir. }\end{array}$ \\
\hline
\end{tabular}

\section{A. Makro Yapı}

\section{Tematik Yapı}

Bu videonun başlıkla kısmen eşleştiği görülmektedir. İlk okunduğunda yoğun bir ziyaretçi akını olduğu izlenimi verilmeye çalışıldığı anlaşılmaktadır. Ancak ziyaretçi sayısının çok yüksek olduğu düşünülmediğinden kısmen ifadesi kullanılmıştır. Video başlığında olduğu gibi 500 bin kişinin ziyaret ettiği röportajın yapıldığı kişi tarafından vurgulanmaktadır. Tanım kısmında videodaki röportajın yazıya dönüştürüldüğü görülmekte ve videoyu hazırlayan haber ajansının internet üzerindeki erişim adreslerine yer verildiği görülmektedir. Kategori olarak "Haberler ve Politika" tercih edilmiştir.

\section{2. Şematik Yapı}

Durum

1. Videonun Anlatım Dili: Video süresinin yarısına kadar yalnızca görüntü verilirken ardından halk ile röportaj ve akabinde yetkilinin açıklayıcı anlatımları bulunmaktadır. Anlatımda oldukça sade ve anlaşılır bir dil kullanılmıştır.

2. Sonuçlar: Videoya bakıldığında minyatür müzesinin halk tarafından çok fazla beğenildiği anlaşılmıştır. Ziyaretçilerle yapılan görüşmede herkes memnuniyetini dile getirmiştir.

3. Ardalan Bilgisi (Önceki olay da dahil): Videoda herhangi bir ardalan bilgisine rastlanmamıştır.

4. Bağlam Bilgisi: Videoda, müzenin içerisinde yer alan Somuncu Baba'nın yaşamına dair minyatürlerin gösterimi, ziyaretçi röportajları ve yetkilinin bilgilendirmesi yer almaktadır. Videodaki öğeler bir örüntü içerisinde verilmiştir. 


\section{B. Mikro Yapı}

1. Sentatik Çözümleme: Anlatımdaki cümleler genel olarak aktif yapıdadır. Basit ve her kesimden izleyenin anlayacağı şekilde cümleler kurulmuştur. Videodaki cümleler, genel olarak şimdiki zaman ve geniş zaman kiplerinde çekimlenmiştir.

2. Bölgesel Uyum: Müze hakkında açılamalar yapan belediye başkanı, göreve geldikten sonra tadilat ve onarım yaptıklarını ve bu müzeyi ortaya çıkarmaları neticesinde yılda 500 bin kişinin ziyaret ettiğini belirtmekte, açıklamaları nedensellik taşımaktadır.

3. Kelimelerin Seçimleri: Videoda müze, somuncu baba, minyatür gibi kelimeler çoğunlukta ve düz bir anlatım vardır.

4. Retorik: İncelenen videodaki söylemler tamamen görüntüler ile desteklenmektedir. Belediye başkanının bilgilendirmelerinin yanında ziyaretçilerle yapılan samimi röportajlar inandırıcılığ 1 pekiştirmiş̧ir.

Somuncu Baba ve ona atfedilen külliyeye yönelik video analizleri genel olarak incelendiğinde, görüntü, çekim kalitesi, kullanılan ekipmanlar ve video kurgusu açısından önemli eksiklikler olduğu görülmüsstür. Bu eksikliklerin giderilmesi halinde internet teknolojisi ve sosyal medyanın etkisiyle Anadolu erenlerinden Somuncu Baba ve ona atfedilen külliye, daha fazla tanınacaktır. Bu tanınma aynı zamanda Aksaray'ın inanç turizmi potansiyelini de artıracaktır.

\section{SONUÇ ve ÖNERILER}

Turizm, bazı dönemlerde öngörülemeyen kriz anlarına (salgın hastalıklar, ekonomik krizler vb.) rağmen giderek büyüyen bir sektör olarak kendini göstermeye devam etmektedir. Turizmin yaygınlaşması ve gelişmesinde internet ve sosyal medyanın da etkisi artmaktadır. Sosyal medyada turizme ait kültürel değerler ve doğal güzelliklerin paylaşılması bilinirliğinin olumlu yönde etkilemektedir.

Somuncu Baba Külliyesine ilişkin en fazla izlenen videoların analizinin yapılmasına rağmen ilgili videoların izlenme oranlarının oldukça düşük kaldığı görülmektedir. Örneğin yayınlanmış en eski videonun 2013 yılına ait olduğu ve 9.600 civarında bir izlenme oranına sahip olduğu görülmektedir. Çalışmada incelenen videolar arasında en fazla izlenen videonun 2015 yılına ait "video-1" olduğu görülmekte ve onun izlenme sayısının da 18.500 civarında olduğu anlaşılmaktadır. Bu da uzun bir süre yayında kalmalarına rağmen izlenme oranlarının düşük kaldığını göstermektedir. İzlenme oranlarının düşük olması göz önüne alındığında videolara ilişkin link verilmemesinin de etkili olduğu düşünülmektedir. Analize tabi tutulan videolardan en yenisi olan ve aynı zamanda link verilen "video-5" in sadece bir aylık yayınlanma süreci içinde 890 izlenme sayısına ulaşması bu durumu doğrulamaktadır.

Videoların yaygınlaşmasında etiketlemenin de önemli olduğu düşünülmektedir. Birçok kurum ve kişinin etiketlenmesi sayesinde videoların dolaşımının daha da artacağı düşünülebilir. Videoların izlenme oranlarını olumsuz yönde etkileyen konulardan birisi de uygun içerikli videoların oluşturulamamasıdır. Çalışmada incelenen videoların içeriklerinin yetersiz kaldığı düşünülmektedir. Daha doğru ve sistematik bir içerik üretildiğinde insanların videoları daha çekici ve izlenebilir bulacağı değerlendirilebilir. Videoların izlenme, paylaşılma, beğenilme sayılarının artırılması ancak doğru içerik üretimi ile mümkün olacağı varsayılmıştır. Aksaray Somuncu Baba Külliyesini en iyi temsil eden ve en çok izlenmeye sahip videonun bir televizyon kanalın tarafından, üst düzey ekipmanlar ve daha uygun bir kurgu ile çekilmesi yukarıdaki ifadelerle örtüşmektedir. 
Bu konuda inceleme yapacak başka araştırmacılara benzer özelliklere sahip diğer inanç turizm merkezlerine yönelik videolar ile Somuncu Baba' ya yönelik videoların karşılaştırılması önerilebilir. Bilinirliği artırmada Somuncu Baba ve Külliyesine ilişkin faaliyet sayısını artırma (çeşitli anma törenleri) ve bunları uygun içerikle videolar haline dönüştürmek tanıtımdaki eksikliği önemli ölçüde giderebilecektir. Özellikle kamu kurumlarının (Belediye ve İl Kültür Turizm Müdürlüğü gibi) Somuncu Babaya ilişkin hazırlanacak videoları özenli bir şekilde hazırlamaları ve insanların ilgisini çekecek kurgulamalar yapmaları yerinde olacaktır. Aksaray Somuncu Baba Külliyesine ait bir web sitesi veya YouTube kanalı olmayışı bir eksiklik olarak görülmüştür. İnternet üzerinde insanların erişebileceği bir web sayfası oluşturmak ve bu sayfaya YouTube içeriklerini eklemek, inanç turizmi balgamında yerinde bir uygulama olacaktır. Böylece bilinirliği artan Somuncu Baba ve Külliyesi, Aksaray turizmine önemli katkılar sağlayacaktır.

\section{KAYNAKÇA}

Akgündüz, A. (2009). Arşiv Belgeleri Işığında Somuncu Baba ve Neseb-İ Alisi. İstanbul: Osmanlı Araştırmaları Vakfı.

Alaeddinoğlu, F. ve Yıldız, M. Z. (2011). Türkiye'de Kültür Turizmi ve Algılanışı. Atatürk Kültür, Dil ve Tarih Yüksek Kurumu, 1(1), 21-35. Erişim adresi http://www.ayk.gov.tr/wpcontent/uploads/2015/01/ALAEDD\%C4\%B0NO\%C4\%9ELU-Faruk-YILDIZ-Mehmet-ZeydinT\%C3\%9CRK\%C4\%B0YE\%E2\%80\%99DE-K\%C3\%9CLT\%C3\%9CR-TUR\%C4\%B0ZM\%C4\%B0VE-ALGILANI\%C5\%9EI.pdf. [Erişim Tarihi: 22.01.2020].

Başer, Ş. (1995). Şeyh Hamideddin-i Aksaray-i Ebu Hamid-Şeyh Hamid-i Veli (Somuncu Baba). İstanbul: Prestij Matbaacılık.

Çakmak, V. ve Altaş, A. (2018). Sosyal Medya Etkileşiminde Tren Yolculukları: Doğu Ekspresi ile İlgili Youtube Paylaşım Videolarının Analizi. Journal of Tourism and Gastronomy Studies, 6, (1), 390, 408.

Çel, S. (2011). Sürdürülebilir Turizm Kapsamında Burhaniye'nin Alternatif Turizm Potansiyeli. Marmara Coğrafya Dergisi, 24, 332-353.

Çelik, H., ve Ekşi, H. (2008). Söylem Analizi. Atatürk Ĕ̆itim Fakültesi Eğitim Bilimleri Dergisi, 27(27), 99-117.

Çomu, T. (2012). Video Paylaşım Ağlarında Nefret Söylemi: YouTube Örneği. Ankara: Ankara Üniversitesi Sosyal Bilimler Enstitüsü Kadın Çalışmaları Anabilim Dalı, Yayımlanmamış Yüksek Lisans Tezi.

Dondurucu, Z. B., and Uluçay, A. P. (2015). The Hate Speech in New Media Environments: The Analysis of Videos Which Include Hate Speech for Gay People. International Journal of Social Sciences and Education Research, 1(3), 875-902.

Emekli, G. (2005). Avrupa Birliğinde Turizm Politikaları ve Türkiye'de Kültürel Turizm. Ege Coğrafya Dergisi, 14(1-2), 99-107.

Eser, S., Şahin, S. ve Çakıcı, A. C. (Ed.). (2018). Turist Rehberliği. Ankara: Detay Yayıncılık.

Göğebakan, Y. (2015). Dünya Üzerindeki Kültürel Varlıkların Turizme ve Ekonomiye Katkısı. Anadolu Üniversitesi Sanat ve Tasarm Dergisi, 5(2), 48-71.

Güzel, Ö. (2010). Turistik Ürün Çeşitlendirmesi Kapsamında Yeni Bir Dinamik: İnanç Turizmi. Süleyman Demirel Üniversitesi Vizyoner Dergisi, 2(2), 87-100. 
Jovicic, D. (2014). Cultural Tourism in The Context of Relations Between Mass and Alternative Tourism. Current Issues in Tourism, 19(6), 605-612.

Jiménez-Barreto, J., Rubio, N. and Campo, S. (2020). Destination Brand Authenticity: What an Experiential Simulacrum! A Multigroup Analysis of Its Antecedents and Outcomes Through Official Online Platforms. Tourism Management, 77, 104022.

Koo, C., Shin, S., Kim, K., Kim, C., and Chung, N. (2013). Smart Tourism of the Korea: A Case Study. Proceedings of Pacific Asia Conference On Information Systems (PACIS, 18-22/06/ 2013)

Kozak, N., Kozak, A. M. ve Kozak, M. (2014). Genel Turizm - İlkeler ve Kavramlar. Ankara: Detay Yayıncilik.

Reino, S. and Hay, B. (2011). The Use of YouTube As A Tourism Marketing Tool. 2011 TTRA International Conference, Canada: 19-21 June 2011.

Solak, Ö. (2011). Küçük Ağa Romanının Eleştirel Söylem Analizi. Akademik Bakış Dergisi, 26, 1-14.

Tuncer, M. (2018). Destinasyon Pazarlaması ve Transmedya: “The Water Diviner” Üzerine Bir Değerlendirme. Çanakkale Araştırmaları Türk Yıllığı, 16(25), 117-129.

Türker, N., Akça, E. ve Uçar, M. (2019). Dini Mekanları Ziyaret Eden Turistlerin Seyahat Motivasyonları: Kastamonu İlinde Bir Uygulama. Safran Kültür ve Turizm Araştırmaları Dergisi, 2(1), 111-132.

Ulu, M. (2016). Şeyh Hamid-i Veli Somuncu Baba: Hayatı ve Eserleri (H. Yılmaz, ed.). Aksaray: Aksaray Belediyesi Kültür Yayınları.

Wang, S., Yamada, N. and Brothers, L. (2010). A Case Study: Discussion of Factors and Challenges for Urban Cultural Tourism Development. International Journal of Tourism Research, 13(6), 553-569.

Yılmaz, A. B. (2019). Kültür Turları Revaçta. Milliyet. Erişim Adresi: http://www.milliyet.com.tr/gundem/kultur-turlari-revacta-2865249. [Erişim Tarihi: 22.01.2020].

Zhang, H., Gordon, S., Buhalis, D., and Ding, X. (2018). Experience Value Cocreation on Destination Online Platforms. Journal of Travel Research, 57(8), 1093-1107. 